\title{
Adrenergic Signaling in Circadian Control of Immunity
}

\author{
Sarah Leach and Kazuhiro Suzuki* \\ Laboratory of Immune Response Dynamics, Immunology Frontier Research Center, Osaka University, Osaka, Japan
}

Circadian rhythms govern a multitude of physiologic processes, both on a cell-intrinsic level and systemically, through the coordinated function of multi-organ biosystems. One such system-the adrenergic system-relies on the catecholamine neurotransmitters, adrenaline and noradrenaline, to carry out a range of biological functions. Production of these catecholamines is under dual regulation by both neural components of the sympathetic nervous system and hormonal mechanisms involving the hypothalamus-pituitary-adrenal axis. Importantly, both neural and hormonal arms receive input from the body's central clock, giving rise to the observed rhythmic variations in catecholamine levels in blood and peripheral tissues. Oscillations in catecholamine signals have the potential to influence various cellular targets expressing adrenergic receptors, including cells of the immune system. This review will focus on ways in which the body's central master clock regulates the adrenergic system to generate circadian rhythms in adrenaline and noradrenaline, and will summarize the existing literature linking circadian control of the adrenergic system to immunologic outcomes. A better understanding of the complex, multi-system pathways involved in the control of adrenergic signals may provide immunologists with new insight into mechanisms of immune regulation and precipitate the discovery of new therapeutics.

Keywords: sympathetic nervous system, circadian rhythms, adrenergic, immunity, noradrenaline

\section{CIRCADIAN RHYTHMS AND THE ADRENERGIC SYSTEM Circadian Rhythms}

Circadian rhythms are biological processes that exhibit intrinsic, self-sustained oscillations even in the absence of external, environmental cues. In mammals, these processes are maintained at the cellular level by transcriptional feedback loops that regulate expression of biological clock genes in a rhythmic fashion, following an approximately 24 -h cycle. These cell-autonomous clocks are synchronized to function in concert at the bio-systems level, giving rise to the cyclic rhythms observed in, for instance, cardiovascular and endocrine function. Circadian rhythms are entrained by external signals (or "zeitgebers") such as light/dark cycles, temperature, sleep and feeding patterns, which, although not required for the maintenance of endogenous oscillations, function to synchronize the biological clock with the surrounding environment. Circadian rhythms are controlled by a central, light-sensitive "master clock" - the suprachiasmatic nucleus $(\mathrm{SCN})$ - that coordinates the function of peripheral, tissue-regulated- and cell-autonomous-clocks (1). This hierarchical organization supports the synchronization of multi-organ systems while simultaneously maintaining the ability to independently fine-tune or uncouple local responses to circadian signals. 
The SCN is located in the hypothalamus directly above the optic chiasm where it receives input from photosensitive ganglion cells in the retina. Photic signals are transmitted by neural fibers from the retina along the retinohypothalamic tract (RHT), eventually initiating a neurotransmitter-driven signaling cascade involving glutamate, PACAP (pituitary adenylate cyclase-activating polypeptide) and aspartate $(2,3)$. The RHT terminates at the ventrolateral region of the SCN, forming direct contact with $\mathrm{SCN}$ neurons in this region $(4,5)$. Here, neurotransmitter signaling through NMDA (N-methyl-D-aspartate) or AMPA ( $\alpha$-amino-3-hydroxy-5methyl-4-isoxazoleproprionic acid) receptors results in CREB binding to CAMP response elements in promoters of the so-called "clock genes" (6-9). Although this CREB-mediated regulation of clock gene expression is by far the most well-characterized mechanism linking circadian transcriptional feedback loops with photic signals, the search for alternative mechanisms is an area of active investigation (10). Thus, light cues are thought to be integrated into the molecular pathways governing circadian rhythmicity, providing a basis for photic entrainment of various biorhythms.

On a cellular level, control of circadian rhythmicity is thought to involve the interactions of at least two major autoregulatory transcription-translation feedback loops. The central players in the first feedback loop are the CLOCK (circadian locomotor output cycles kaput) and BMAL1 (brain and muscle aryl hydrocarbon receptor nuclear translocatorlike 1) proteins $(11,12)$. CLOCK and BMAL1 interact to form a heterodimer which drives expression of PER (period circadian protein) and CRY (cryptochrome) proteins by binding to E-boxes in the Per1, Per2, Per3, Cry 1, and Cry2 promoters $(13,14)$. PER and CRY, conversely, act as transcriptional repressors by displacing CLOCK-BMAL1 from E-box regulatory elements (15). The second feedback loop involves the nuclear receptors REV-ERB $\alpha, \operatorname{REV}-\mathrm{ERB} \beta$, and $\operatorname{ROR} \alpha$ (retinoic acid receptor-related orphan receptor alpha) (16-18). REV-ERB $\alpha$ and REV-ERB $\beta$ themselves undergo cyclic, circadian expression under the transcriptional activation of CLOCK-BMAL1 and repression by CRY-PER, while also exhibiting repressive control of CLOCK and BMAL1 expression (18). ROR $\alpha$, on the other hand, competes with REV-ERB $\alpha$ to drive BMAL1 expression (19). Together, these interlocking, auto-regulatory transcriptiontranslation loops constitute the molecular basis for the cyclic gene expression driving circadian biorhythms. More extensive reviews of the molecular mechanisms underlying circadian rhythmicity can be found elsewhere (20-22).

\section{The Adrenergic System}

The adrenergic system is a neuro-hormonal system that regulates a range of physiological functions which are carried out through production of the catecholamines, adrenaline (epinephrine; EP) and noradrenaline (norepinephrine; NE). EP and NE signal through adrenergic receptors expressed on a wide variety of tissues and cell types, and are involved in processes such as regulation of cardiac function $(23,24)$, vascular remodeling and fat metabolism $(25,26)$, smooth-muscle-mediated vasoand broncho-constriction (27), placental development (28), and control of immune function (29-31). Catecholamine production is regulated systemically via humoral messengers generated by the hypothalamus-pituitary-adrenal (HPA) axis, and locally by neural components of the sympathetic division of the autonomic nervous system. EP and NE are synthesized at a 4-1 ratio (favoring EP) (32) in the adrenal medulla and released into the bloodstream to carry out systemic functions. Neurons of the sympathetic nervous system (SNS), on the other hand, produce and predominantly secrete NE at discrete locations marked by the presence of adrenergic nerve terminals, thereby supplying peripheral tissues with highly localized NE signals. Importantly, the adrenergic system is one of the many biological systems thought to be under circadian control.

\section{Rhythmic Catecholamine Production}

In 1943 Pincus (33) made the preliminary observation that the concentration of certain adrenal hormones in urine oscillated following a night-day pattern. Two decades later, isolated adrenal glands were found to exhibit intrinsic metabolic rhythmicity in culture, pointing to the existence of a self-sustained, endogenous clock (34). Following this discovery, a role for the SCN as a regulator of circadian adrenal function was suggested by ablation of circadian oscillations in adrenal corticosterone content following lesioning of the SCN (35). Consistent with these reports detailing both endogenous and exogenous control of circadian fluctuations in adrenal function, diurnal rhythms in plasma EP and NE levels were also described. Humans were found to have low circulating catecholamine levels during the night and high levels during the day (36), while rodents exhibited the opposite pattern (corresponding to opposite periods of activity) (37).

However, although EP and NE exhibited, overall, similar 24$\mathrm{h}$ rhythms in circulation, many early studies reported differences in the maintenance of EP and NE oscillations under free-running conditions (or in the absence of entrainment). Specifically, EP was reported to exhibit clear, self-sustained rhythmicity, while NE levels were found to adjust rapidly to sleep/wake patterns, leading many to conclude that rhythmicity in circulating NE levels was just a result of sleep or even postural cues $(36,38-$ 40). Later studies more clearly demonstrated this distinction by showing that NE cycles were abolished under constant light or food-deprivation conditions $(40,41)$. These findings led to the conclusion that while oscillations in circulating EP appear to be circadian and are regulated by the HPA axis, cyclic variations in circulating $\mathrm{NE}$ exist only in the presence of cyclic, external zeitgebers and, therefore, cannot be considered truly circadian according to the strictest definition.

There is evidence, however, that the release of NE from sympathetic neurons within tissues is under circadian control. This was pointed to, for example, by the finding that NE in cerebrospinal fluid (CSF) [which is likely neuron-derived, as NE does not readily pass the blood-CSF barrier (42)] exhibits a circadian rhythmicity that is maintained despite disruption in light cycles (43). In addition, NE turnover in the pineal gland was demonstrated to exhibit an endogenous, 24-h rhythmicity that was maintained in blinded rats. The authors concluded that NE turnover in the pineal gland likely reflected daily rhythms in NE 
release from sympathetic neurons within this tissue (44). As a related side note, neuron-derived NE signals activate pinealocytes in the pineal gland through $\beta 2$-adrenergic receptors, driving circadian oscillations in the production of melatonin from its metabolic precursor, serotonin $(44,45)$. Melatonin has been demonstrated to exhibit a range of effects on immunity including control of cytokine production by neutrophils and lymphocytes $(46,47)$, inhibition of nitric oxide synthesis (48) and promotion of immune cell migration $(49,50)$, to name a few examples. Thus, circadian NE rhythms feed into rhythmic variations in indolamine metabolism, providing another, albeit indirect, way for the noradrenergic system to influence immune responses.

\section{Regulation of Systemic Catecholamine Production by the HPA Axis}

Release of EP and NE into circulation has long been thought to be regulated by the hypothalamic-pituitary-adrenal (HPA) axis. Consistent with the observation that circulating catecholamine levels (particularly EP) exhibit circadian rhythmicity, neuroanatomical tracing studies demonstrated that SCN neurons of the circadian master clock are directly linked to the PVN (paraventricular nucleus neurons) of the hypothalamusoften considered the driver of the HPA axis (51). While the specific mechanisms by which signals governing circadian rhythmicity are propagated remain incompletely defined, various neurotransmitters have been proposed to be involved in SCNPVN communication including vasopressin (52), vasoactive intestinal peptide (VIP) $(53,54)$ and neuromedin $U$ (55). Moreover, the hypothalamus is known to release corticotropinreleasing hormone $(\mathrm{CRH})$ and vasopressin in circadian fashion $(52,56)$. These PVN-derived peptides regulate pituitary function and drive the secretion of adrenocorticotropic hormone $(\mathrm{ACTH})$, which then incites the adrenal cortex to produce glucocorticoids (cortisol in humans; corticosterone in rodents). Within the adrenal gland, glucocorticoids are transported to the medulla where chromaffin cells produce NE. Here, glucocorticoids activate the enzyme, phenylethanolamine $\mathrm{N}$ methyltransferase (PNMT), which is required for the conversion of NE to EP $(57,58)$. Thus, cyclic variation in HPA signals are likely particularly important in driving diurnal oscillations in adrenal EP levels. Although our understanding of these processes remains far from complete, signals from the body's central, master clock are, in this way, thought to be translated into rhythmic variations in neurotransmitters and hormonal messengers, which influence peripheral sites in circadian fashion. This includes the cyclic release of catecholamines by the adrenal gland into the bloodstream.

\section{Regulation of Systemic Catecholamine Production by the Sympathetic Adrenal Medullary Axis (SAM)}

In addition to HPA-mediated regulation (and of arguably greater physiological importance for the production of adrenal catecholamines), adrenal glands are also innervated by neurons connected (via a polysynaptic pathway) to the SCN, providing a mechanism for direct regulation of adrenal catecholamine production by the body's master clock (59). Innervation of the adrenal medulla by preganglionic sympathetic neurons emanating directly from the spinal cord $(60,61)$, as well as splanchnic (62) and vagus nerves $(63,64)$, has also been reported. Neural stimulation of chromaffin cells and subsequent catecholamine secretion is thought to be induced by cholinergic signals, much in the same way that post-ganglionic, sympathetic neurons are activated to secrete NE by pre-ganglionic neurons in sympathetic ganglia $(65,66)$.

Consistent with these anatomical studies demonstrating neural connections between adrenal glands and the SCN, adrenal clock gene expression has been shown to be responsive to light entrainment (67). Furthermore, light-induced, acute activation of adrenal nerves is abolished in SCN-lesioned mice (68). This, combined with the observation that the rhythmicity in adrenal clock gene expression is unaltered in hypophysectomized rodents (69), lends support to the notion that adrenal glands may be subject to circadian oversight via neural, as well as hormonal, pathways. Thus, while HPA axis-mediated stimulation of chromaffin cells influences the ratio of EP to NE levels (70) in a cyclic fashion via glucocorticoid-driven PNMT activation (71), adrenal secretion of catecholamines also involves a local neural component-importantly, one that displays circadian rhythmicity (72) and is directly entrained by environmental cues organized in the SCN $(68,69)$. Although both the HPA axis and SAM axis potentially contribute to the oscillations in circulating catecholamine levels, the relative importance of these pathways under physiological conditions is not entirely clear. However, it has been suggested that the effects of the neuronal pathway may be manifest more prominently during prolonged or chronic disease states in which adrenal output and pituitary output do not correlate well (73-75) (Figure 1).

\section{Tissue-Localized Catecholamine Production by Sympathetic Neurons}

Sympathetic neurons innervate, in addition to adrenal glands, a wide range of tissues including primary and secondary lymphoid organs $(76,77)$. The primary neurotransmitter thought to be produced by SNS nerve terminals is NE (78). In circulation, $\mathrm{NE}$ concentrations are reported to be in the picomolar to low nanomolar range (79), but under conditions of strong sympathetic stimulation, the tissue concentration at nerve endings may reach micromolar levels (80). Given the relatively low amount of NE in the blood, one might question whether circulating NE has a significant physiological role at steady state or under healthy conditions. Indeed, urinary concentrations of NE remain constant after adrenalectomy in humans (81) suggesting that neuron-derived $\mathrm{NE}$ in peripheral tissues may be more physiologically relevant for NE-specific functions than circulating NE. In regards to immune function, the observation that lymphoid tissue exhibits diurnal fluctuations in $\mathrm{NE}$ is particularly noteworthy, pointing to possible circadian control of SNS neuronal NE output (82).

\section{Adrenergic Receptors and Their Ligands}

Catecholamines signal through adrenergic receptors, a class of $G$ protein-coupled receptors. Broadly classified as $\alpha$ - or 


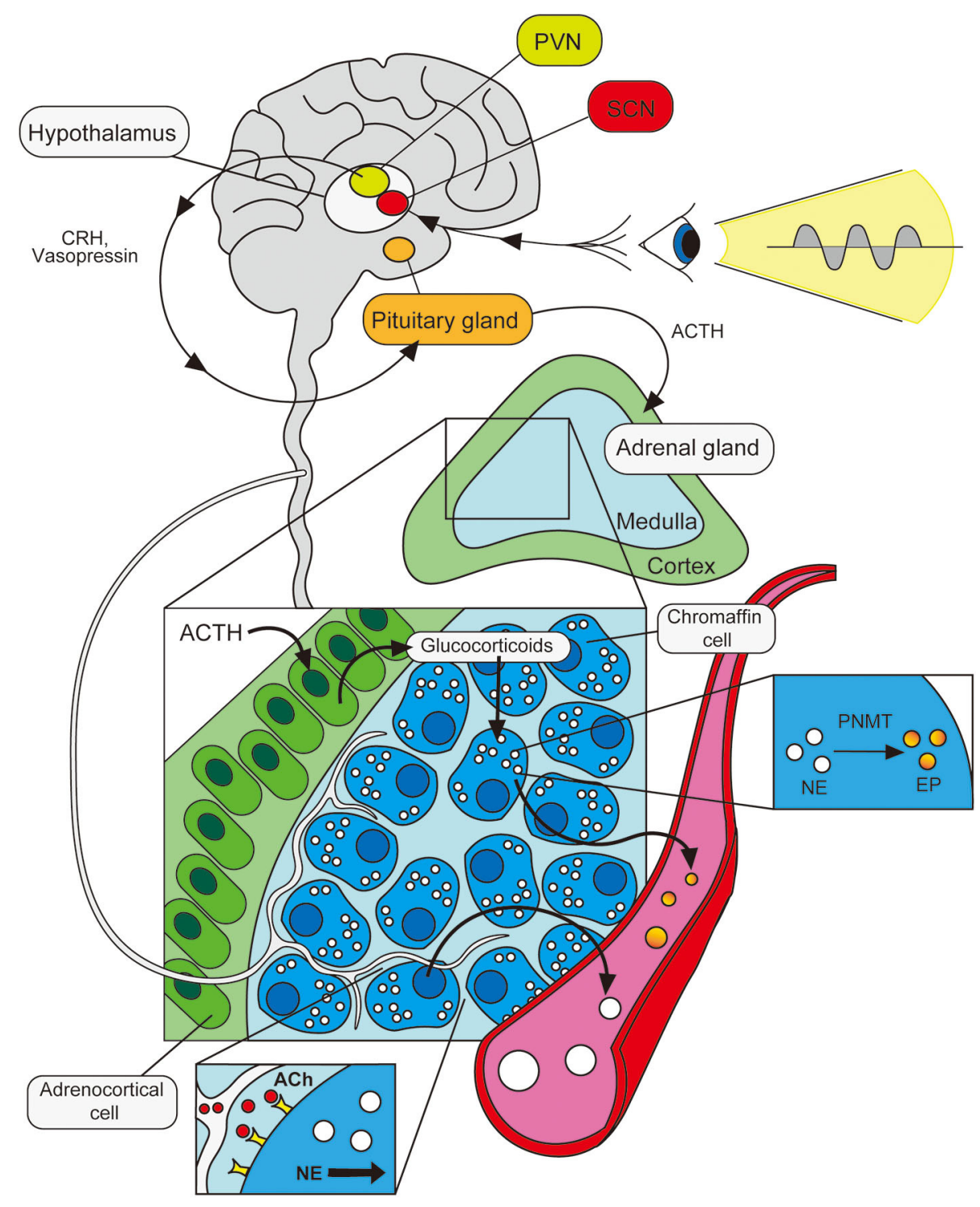

FIGURE 1 | Circadian control of adrenal catecholamine output. Photic signals entrain the body's master clock in the hypothalamus (SCN), sending oscillating signals to the PVN. The PVN propagates these neural signals to the pituitary gland via various neurotransmitters and hormonal messengers. The pituitary gland responds by releasing ACTH, which drives adrenocortical cells in the adrenal gland to produce glucocorticoids. These signal to chromaffin cells in the medulla, activating the enzyme, PNMT, which catalyzes the conversion of NE stores into EP for release into the bloodstream. The adrenal medulla is also innervated by acetylcholine (ACh)-producing neurons which also respond to cyclic light signals in the SCN. Stimulation of these neurons activates chromaffin cells, driving the release of NE into the bloodstream in a cyclic fashion.

$\beta$-adrenergic receptors ( $\alpha$-ARs, $\beta$-ARs), $\alpha$-ARs exhibit higher affinity for NE whereas $\beta$-ARs exhibit higher affinity for EP (83, 84) (although neither type of receptor exhibits exclusive binding to NE or EP). These two classes are further subdivided into three $\alpha 1-\left(\alpha_{1 \mathrm{~A}}, \alpha_{1 \mathrm{~B}}\right.$ and $\left.\alpha_{1 \mathrm{D}}\right)$, three $\alpha 2-\left(\alpha_{2 \mathrm{~A}}, \alpha_{2 \mathrm{~B}}\right.$ and $\left.\alpha_{2 \mathrm{C}}\right)$, and three $\beta$ - $(\beta 1, \beta 2$ and $\beta 3)$ adrenergic receptor subtypes (85-88) which display varied tissue-tropism and activate distinct signaling pathways. While varying degrees of expression of all three AR types have been reported on different hematopoietic cells, $\beta 2$ ARs are thought to be predominantly expressed (31) [albeit with a notable absence on both resting and activated type 2 helper
T cells (89, 90)]. Examining expression of different receptor subtypes is hindered by lack of specific antibodies and receptor subtype-specific ligands. As a result, current understanding of receptor expression comes largely from transcript-level analyses or competitive binding/saturation studies; more comprehensive studies are still needed in this regard.

\section{Catecholamine Signaling Pathways}

Signaling through adrenergic receptors reportedly modulates various cellular functions or properties, including (but not limited to) cell cycle and proliferation (91, 92), migration (93), 
and cytokine (94) and antibody (95) production. Although historically, signaling through $\beta$-ARs has often been associated with anti-inflammatory outcomes, in more recent years, the ability of $\beta$-ARs to mediate context-dependent, pro- and antiinflammatory effects has become more widely appreciated (29, 94, 96). $\beta$-ARs signal through the G-protein, $\mathrm{G} \alpha_{s}$. Activation of $\mathrm{G} \alpha_{\mathrm{s}}$ leads to activation of adenylate cyclase (AC), which catalyzes the conversion of adenosine triphosphate (ATP) into cyclic adenosine monophosphate (cAMP). Subsequently, cAMP activates protein kinase A (PKA), which is responsible for the activation of downstream transcription factors. Although all $\beta$ ARs signal through $\mathrm{G} \alpha_{s}$, it is thought that receptor subtypespecific differences in signal transduction are a result of specific localization of, for instance, membrane or cytosolic AC and PKA isoforms which form unique signalosomes, leading to the compartmentalization of cAMP pools which can then selectively target distinct physiological pathways (97-99). Non-canonical, G-protein-independent signaling through $\beta$-ARs has also been described (involving $G$ protein-coupled kinases (GRKs) and $\beta$-arrestins), leading to the activation of ERK1/2 or MAPK pathways $(100,101)$. Intracellular cAMP levels have also been reported to influence, among other things, transcription of various cytokines in immune cells. For instance, increased cAMP leads to upregulation of IL-10 gene expression (102) while inhibiting IL-12 and TNF- $\alpha$ transcription $(102,103)$.

Much less is known regarding $\alpha$-AR signaling on immune cells. Although not an exhaustive list, expression of $\alpha 1$-ARs has been reported on murine HSC progenitors (104), immature dendritic cells (93), mast cells (105), and human NK cells (106), while $\alpha 2$-AR expression has been reported on Kupffer cells (107), dendritic cells (108), NK cells (106), and occasionally on human lymphocytes $(109,110)$. Most of our current knowledge regarding signal transduction comes from studies of cardiomyocytes in which $\alpha 1$-ARs are coupled to $\mathrm{G} \alpha_{\mathrm{q}} \mathrm{G}$ proteins. Ligand binding then leads to the activation of PLC $\beta 1$, downstream calcium signaling and activation of PKC (111). $\alpha 2$ ARs, on the other hand, associate with $\mathrm{G}_{\mathrm{i}}$-type $\mathrm{G}$ proteins, and drive inhibition of AC and reduction of cAMP levels upon ligand binding $(112,113)$, potentially providing a means to counteract the effects of $\beta$-AR stimulation.

\section{CATECHOLAMINES IN THE CENTRAL NERVOUS SYSTEM AND DISEASE \\ Catecholamine Production in the Central Nervous System}

The locus coeruleus (LC) is the primary source of NE in the central nervous system, sending projections throughout the brain (114). It is thought to have a role in attention and arousal (115), as well as in stress-responses such as fear or anxiety $(116,117)$. Moreover, retrograde tracing experiments have revealed trans-synaptic circuits connecting the SCN and LC, and providing a basis for circadian control of LC activity $(118,119)$. In addition to circadian effects on LC firing, however, LC-derived NE levels both influence and are heavily influenced by sleep state (being completely absent during REM sleep) and changes in vigilance or alertness $(120,121)$, making rhythms in brain NE levels quite sensitive to fluctuation. This difficulty in assessing the specific circadian contribution to NE oscillations in brain tissue has proven a challenge to studies that might attempt to directly link circadian control of central catecholamine production and immune function. Nevertheless, indirect effects of LC-derived NE on immunity are expected to exist, for instance, through modulation of sleep and its general impact on whole body function.

\section{Catecholamines in the Central Nervous System and Immunity}

The blood-brain barrier hinders direct interactions between LCderived NE and most immune cell subsets. However, microgliathe brain's resident innate immune cells-are known to be highly sensitive to catecholamine signals, expressing higher levels of $\beta 2$-adrenergic receptors than any other cell type in the brain $(122,123)$. Studies in mice have demonstrated an inhibitory role for LC-derived NE on microglial function involving changes in activation, nitric oxide production, tissue surveillance and gross morphology (124-126). Thus, one may easily imagine that circadian oscillations in NE coordinate microglia-neuron dynamics to promote homeostasis under normal physiological conditions, and that perturbations in adrenergic signaling might be particularly deleterious (or perhaps even a causative factor) in various neurological disease states. Indeed, LC dysfunction or degeneration is widely observed at early stages in both Alzheimer's disease and Parkinson's disease patients (127-129).

\section{CIRCADIAN CONTROL OF IMMUNE CELL TRAFFICKING MEDIATED BY ADRENERGIC SIGNALS}

\section{Diurnal Variation in Leukocyte Trafficking Patterns}

The most well-characterized means through which adrenergic signals exert circadian control over immunity is by regulation of cell trafficking. Diurnal variation in the number of blood circulating leukocytes was reported as early as the 1940s in both mice and humans $(130,131)$, with most reports describing peak blood leukocyte numbers during the inactive period. Some discrepancies exist, however, in the literature regarding cell-type-specific, day vs. night circulation patterns (130, 132-136). Nevertheless, this phenomenon seemed to be linked to adrenergic function as administration of adrenal or pituitary hormones resulted in blood lymphopenia (137) and adrenalectomy abolished cyclic variations in circulating leukocyte numbers $(133,138)$. As these early studies all pointed to a role for systemic (endocrine) catecholamine-mediated regulation of cyclic variation in leukocyte circulation, an important development in our understanding of this process was the finding that tissue-localized catecholamine signals originating from sympathetic nerve terminals could also significantly influence diurnal patterns in leukocyte migration between blood and peripheral tissues. 


\section{Adrenergic Signaling in Stromal Cells Controls Immune Cell Egress From BM}

Hematopoietic stem and progenitor cells (HSPCs) are constitutively released from BM into the circulation at steady state. However, mobilization of hematopoietic progenitors is dramatically increased under inflammatory conditions or "emergency" states in anticipation of increased requirements for hematopoietic output. Expression of CXCL12 within bone tissue is known to be important for retention of CXCR4 ${ }^{+} \mathrm{HSPCs}$ in hematopoietic niches and suppression of their mobilization. Conversely, granulocyte colony-stimulating factor (G-CSF) has long been recognized for its strong, mobilization-promoting properties. While exploring the mechanisms underlying GCSF-induced HSPC mobilization, Katayama et al. made the somewhat surprising observation that destruction of peripheral adrenergic neurons by chemical sympathectomy (6-OHDA(6-hydroxydopamine) administration), or treatment of mice with a $\beta$-AR antagonist led to a significant reduction in G-CSFdependent, HSPC mobilization (139). This pointed to a role for neuron-derived adrenergic signals in this phenomenon. However, $\beta 2$-AR agonist stimulation alone did not promote mobilization, suggesting that G-CSF and adrenergic signals somehow functioned cooperatively in this process. The authors also demonstrated a correlation between decreased osteoblast CXCL12 expression and HSPC mobilization. In conclusion they proposed that G-CSF suppresses CXCL12 production by osteoblasts, thereby promoting HSPC mobilization. In parallel, G-CSF and sympathetic neuron-derived NE signals were suggested to contribute to this process by some undefined mechanism. Although this initial study simply pointed to a role for adrenergic signals in HSPC mobilization, several subsequent studies have since sought to address the mechanistic questions raised by these observations.

In 2008, Méndez-Ferrer et al. demonstrated that the diurnal variation in HSPC trafficking between BM and blood is a true, circadian phenomenon, as the observed rhythmicity was maintained under constant dark conditions and was abolished in Bmal1-deficient mice (140). The authors also confirmed, via surgical sympathectomy of the hind leg, that local, neuronderived adrenergic signals in the BM were required for this process. Similar to the report by Katayama et. al., downregulation of CXCL12 expression was proposed to be the mechanism driving HSPC egress. However, in contrast to previous reports, Méndez-Ferrer and colleagues demonstrated that adrenergic signals were detected by $\beta 3$-ARs (rather than $\beta 2$-ARs) on some non-osteoblast, BM stromal subset [later proposed to be nestin $^{+}$mesenchymal stem cells (141)]. Moreover, stimulation of $\beta$-ARs with a non-subtype-specific $\beta$-agonist (isoprenaline) alone was sufficient to promote HSPC egress (Figure 2). This study provided intriguing evidence that circadian control of adrenergic signals may be discretely regulated in peripheral anatomic locations (such as the BM) by the sympathetic nervous system. The finding that localized, surgical sympathectomy could abolish circadian oscillations in HSPC output from BM, however,
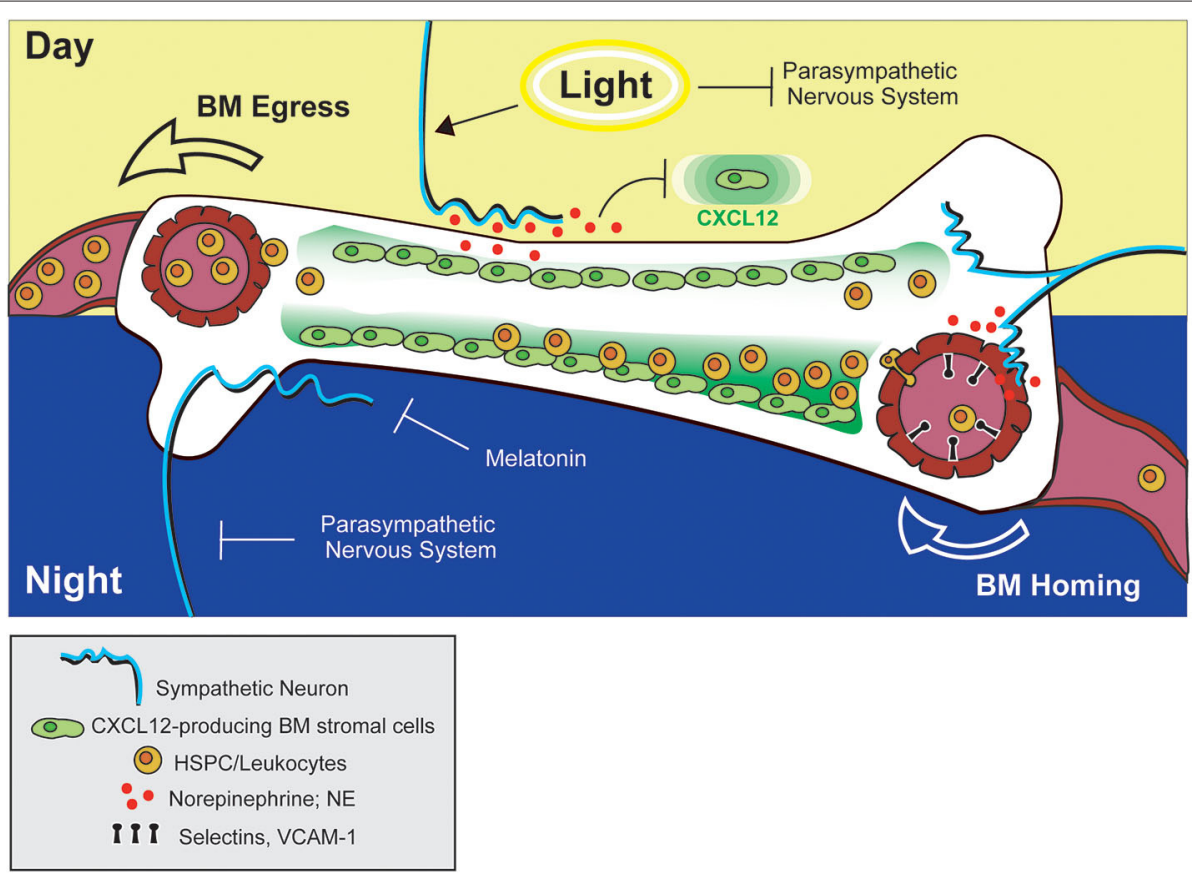

FIGURE 2 | Adrenergic control of leukocyte and HSPC trafficking to and from BM. Circadian stimulation of sympathetic neurons drives down-regulation of CXCL12 in the BM, facilitating HSPC egress into circulation during the day (in mice). At night, adrenergic signals from sympathetic neurons promote upregulation of adhesion molecules by blood endothelial cells in bone tissue, promoting BM homing of leukocytes. The combined actions of melatonin and the parasympathetic nervous system may also function to prevent down-regulation of CXCL12 (and BM egress) during this time. 
seems at odds with early studies reporting similar findings after adrenalectomy and raises questions regarding the relative importance of tissue-localized vs. systemic adrenergic signals in driving BM egress of immune cells. To our knowledge, a sideby-side comparison of the effects of adrenalectomy and surgical sympathectomy on circulating immune cell subsets has not been carried out, but would help shed some light on this issue.

\section{Adrenergic Signaling Mediates Immune Cell Recruitment to Peripheral Tissues}

The concept that adrenergic signals could influence circadian variations in HSPC circulation was later expanded by studies examining the effects of adrenergic signaling on immune cell trafficking to peripheral tissues at rest or under inflammatory conditions. Scheiermann et al. reported that variation in recruitment of leukocytes from blood to BM or skeletal muscle also exhibited diurnal tendencies, with rhythms oscillating in antiphase to that observed for HSPCs traveling from BM to blood (142). This phenomenon exhibited genuine, circadian characteristics as shown by ablation of oscillatory patterns in Bmal1-deficient mice (which lack a core component of the molecular circadian clock) and, conversely, maintenance of these patterns in the absence of light. The cyclic recruitment of leukocytes to peripheral tissues coincided with cyclic variations in expression of different tissue-specific adhesion molecules and chemokines expressed by endothelial cells at the site of extravasation. Diurnal variation in ICAM-1 and CCL2 was observed in skeletal muscle endothelial cells, while expression of P-selectin, E-selectin and VCAM-1 fluctuated within BM endothelium (Figures 2, 3). Importantly, surgical sympathectomy to denervate the $\mathrm{BM}$ or cremaster muscle abolished both cyclic leukocyte recruitment and oscillations in adhesion molecule expression, suggesting that, similar to their role in HSPC egress from BM, adrenergic nerves may provide tissue-specific signals that drive local changes in expression of guidance cues, thereby instructing immune cell trafficking in a diurnal fashion corresponding to the circadian nature of the adrenergic signals they provide. Adoptive transfer studies using receptor knock-out mice pointed to a role for both $\beta 2$ - and $\beta 3$-ARs in this process (although only a requirement for $\beta 3$-AR signaling could be confirmed using a similar agonist-based approach). Finally, the cyclic recruitment of leukocytes to peripheral tissues was shown to influence the pathological severity of various types of inflammatory challenge in disease models including septic shock and sickle cell vasoocclusion (142).

One major question raised by these findings was how temporal changes in BM egress and recruitment could sustain overall cyclic patterns in immune cell circulation when both processes were reported to be governed by the same signals. While Scheiermann et al. reported that adrenergic nerves signal through $\beta 3$-ARs on $\mathrm{BM}$ endothelium driving increased expression of selectins and VCAM-1 to promote immune cell recruitment to BM (142), Méndez-Ferrer et al. reported that adrenergic nerves signal through $\beta 3$-ARs in BM to promote downregulation of CXCL12 expression and HSPC egress (140). How could these seemingly opposing mechanisms function in concert?

Related to this apparent paradox, Golan et al. reported that HSPC numbers in BM exhibit, not one but two, peaks and troughs during a single day/night cycle-one at night, and one after morning light exposure (135). The authors proposed that the morning HSPC peak coincides with a transient increase in NE and TNF levels in the BM driving $\beta 2$-AR-mediated HSPC proliferation and differentiation, which is followed by a wave of HSPC egress into the bloodstream mediated by $\beta 3$ AR-dependent processes. In addition, a second, night-time peak in BM HSPC numbers overlaps with a second NE and TNF burst during which melatonin was shown to inhibit HSPC egress and differentiation (Figure 2). In the context of the previously mentioned reports, these two different HSPC BM peaks could conceivably be attributed to the alternate adrenergic mechanisms driving BM egress and recruitment. Under this interpretation, the light-induced HSPC peak could represent the NE and TNFinduced HSPC proliferative burst that is followed by NE-driven egress via mechanisms described by Méndez-Ferrer et al. (140), while the night-time peak might represent the effect of BM recruitment driven by NE signals as reported by Scheiermann et al. (142). Although this dual peak model provided a potential explanation for altered temporal discernment of these two adrenergic-driven processes in mice, in humans, light exposure coincides with the beginning of the active phase. In this case, it would be expected that the light-induced and active-phase NE peaks would at least partially overlap, making it unclear whether such a model is equally relevant for both diurnal and nocturnal species.

Recently another layer of complexity was introduced to account for the different temporal responses to adrenergic signals in BM by studies examining the additional contribution of the parasympathetic nervous system and cholinergic signaling in this process. Using Gfra2 (GDNF family receptor $\alpha 2$ )-deficient mice as a model of parasympathetic deficiency, García-García et al. showed that parasympathetic nervous system-derived cholinergic signals suppress excessive sympathetic noradrenergic activity (143). At night, this may function to prevent $\beta 3$-ARmediated HSPC egress, while permitting $\beta 2$-AR-driven BM homing. During the day, however, inhibition of parasympathetic activity by light exposure permits the egress of HSPCs from $\mathrm{BM}$ via noradrenergic, $\beta 3$-AR-mediated mechanisms (Figure 2). Supporting this model, the authors also reported diurnal oscillations in $\beta 2$ - and $\beta 3$-AR expression in $\mathrm{BM}$, with $\beta 2-\mathrm{AR}$ higher at night, and $\beta 3$-AR preferentially expressed during the day (143).

\section{Immune Cell-Intrinsic Adrenergic Signaling}

Initial studies examining the function of adrenergic signals in immune cell trafficking largely focused on the effects of catecholamines on non-hematopoietic cell types and their indirect effect on immune subsets. Nakai et al. brought further insight to the field with the finding that immune cellintrinsic adrenergic signaling has the potential to alter a cell's migratory capability (144). This study began with the preliminary observation that treatment of mice with $\beta 2$-AR agonists led to 


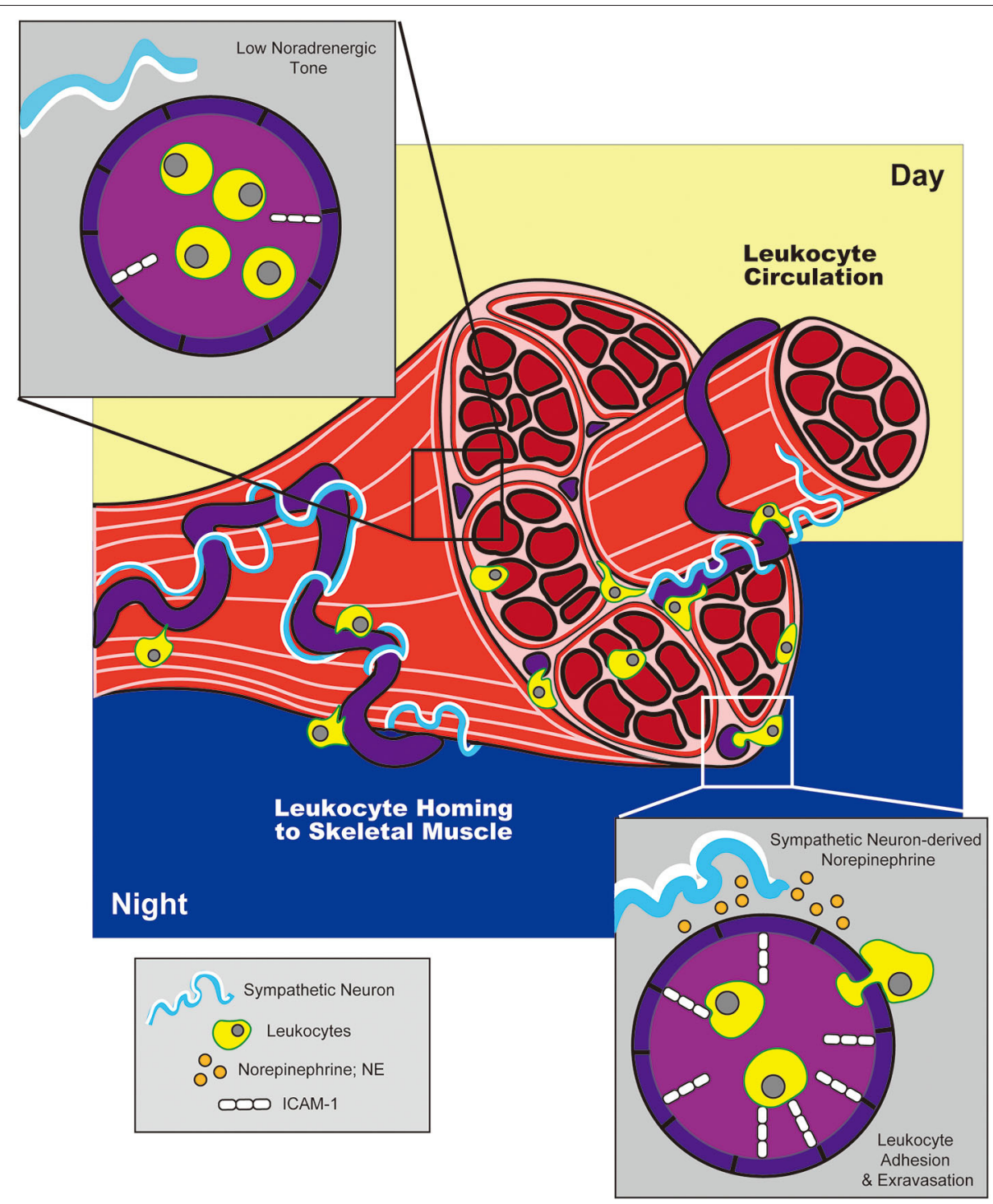

FIGURE 3 | Adrenergic control of circadian leukocyte trafficking to skeletal muscle. During the night (in mice), adrenergic signals from sympathetic neurons drive upregulation of adhesion molecule, ICAM-1, on blood endothelial cells in skeletal muscle. This promotes leukocyte trafficking to and extravasation into tissue during the night, while reduced ICAM-1 expression during the day facilitates return to circulation.

a rapid decrease in the number of circulating lymphocytes in both blood and lymph-a response that was largely lymphocyteintrinsic, as later demonstrated using BM chimeras. Follow-up experiments showed that $\beta 2$-AR stimulation effectively blocked lymphocyte egress from lymph nodes (LNs) leading to the concomitant reduction of lymphocyte numbers in circulation. Notably, while B cells, $\mathrm{CD} 4^{+}$and $\mathrm{CD}^{+} \mathrm{T}$ cells all responded to adrenergic stimulation, the effect was most pronounced in the $\mathrm{B}$ cell compartment, likely as a result of higher intrinsic $\beta 2$ AR expression within this population. Moreover, LN-innervating sympathetic neurons were proposed to be the source of these adrenergic signals as 6-OHDA treatment led to a reduction in the number of lymphocytes retained in entry-blocked LNs (treated with integrin-neutralizing antibodies) compared to those in innervated controls (It should be noted, however, that the contribution from adrenal gland-derived catecholamines cannot be formally excluded). Prolonged $\beta 2$-AR stimulation was shown to have a clear physiological impact on the severity of inflammatory T cell-driven responses in both the mouse model of multiple sclerosis, EAE, and delayed-type hypersensitivity (DTH) responses. These effects were mediated by the inhibition of $\mathrm{T}$ cell egress from LNs and, therefore, inhibition of migration to sites of disease progression (the central nervous system in EAE and the skin in DTH).

The mechanism by which adrenergic signals promote LN retention of lymphocytes was shown to involve increased sensitivity of retention-promoting chemokine receptors, CXCR4 and CCR7, for their respective ligands following co-stimulation 


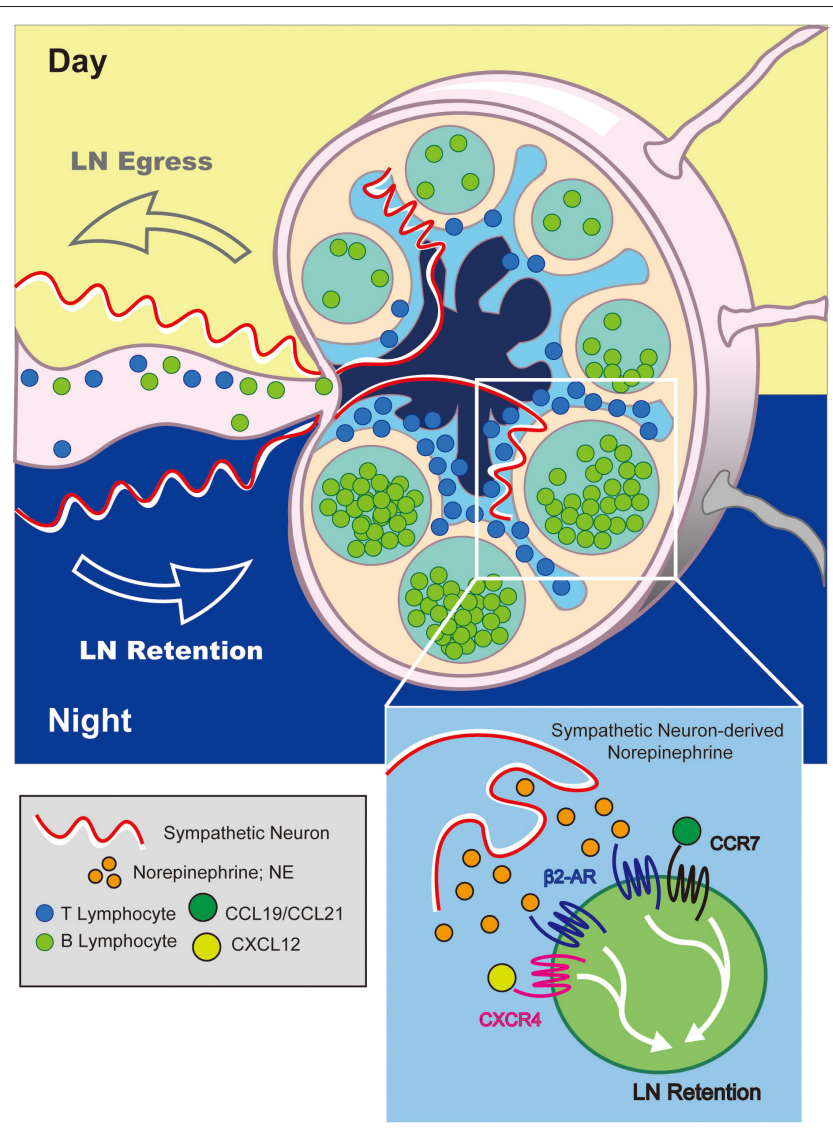

FIGURE 4 | Adrenergic control of diurnal LN egress and lymphocyte retention. At night (in mice), adrenergic signals from sympathetic neurons stimulate $\beta 2$-ARs expressed on $L N$-resident lymphocytes. This increases the sensitivity of lymphocytes to CCR7 and CXCR4-mediated LN-retention signals inhibiting their migration back into lymph fluid. Conversely, reduction in adrenergic tone during the day promotes lymphocyte egress.

through the $\beta 2$-AR (Figure 4). This was evidenced by prolonged Rac1 GTPase activation following co-stimulation, and was further supported by findings from membrane co-localization and immunoprecipitation experiments which pointed to potential physical interactions between $\beta 2$-AR and CCR7 or CXCR4. Furthermore, in vitro migration assays demonstrated enhanced chemotactic responses in lymphocytes receiving dual $\beta 2-\mathrm{AR}$ agonist and chemokine stimulation. Importantly, this mechanism was subsequently proposed to constitute the basis for diurnal oscillations in lymphocyte recirculation through lymph nodes in response to sympathetic neuron-derived signals (82).

Given that adrenergic signals are produced in a circadian manner from sympathetic nerve terminals, it followed that $\beta 2$ AR-mediated control of lymphocyte retention in LNs might also contribute to the daily rhythmicity observed in circulating immune cells. In continuation of these previous studies (144), Suzuki et al. demonstrated that the diurnal fluctuations in blood- and lymph-circulating lymphocyte numbers varied in antiphase to that in LNs, with the active phase exhibiting high lymphocyte numbers in LNs, correlating with high LN adrenergic tone (82). These night/day fluctuations in LN lymphocyte numbers were abrogated after chemical denervation with 6OHDA, suggesting that adrenergic nerves were providing the signals regulating cyclic LN egress. Moreover, the cyclic changes in lymphocyte numbers were dependent on lymphocyte-intrinsic $\beta 2$-AR expression. Although not directly shown, the authors propose that this phenomenon likely also involved the enhanced sensitivity of lymphocytes to chemokine receptor stimulation under conditions of co-adrenergic stimulation as previously reported (144) (Figure 4). Finally, the authors demonstrated a very clear difference in the magnitude of the adaptive immune response elicited following immunization at night vs. during the day, with enhanced antibody, germinal center and $\mathrm{T}$ follicular helper cell generation evident after night-time immunization, when circadian NE signals in mice are known to be highest. Thus, this study clearly demonstrated that adrenergic signaling does not always lead to immuno-suppressive outcomes, but may, rather, support adaptive immunity to promote host defense in a context-dependent manner.

Apart from the reported role for adrenergic receptors in circadian lymphocyte trafficking through lymph nodes, others have reported that cell-intrinsic clocks may drive diurnal variation in lymphocyte numbers in secondary lymphoid organs (145). The role of cell-intrinsic clocks in lymphocyte function, however, has been somewhat disputed in recent years with some groups reporting no or limited effects (146) and others reporting, for instance, effects on lymphocyte differentiation (147). Given the multi-tiered organization of circadian control mechanisms, it may be argued that both central clock-mediated, adrenergic signaling and cell-intrinsic clocks may participate to an extent in this phenomenon. Although analysis of molecular, cell-intrinsic or central circadian clocks were not carried out in the study by Suzuki et al., sufficient evidence of circadian regulation of sympathetic neuron-derived NE signals exists to make a strong case for circadian control of lymphocyte egress from LNs as observed in this study (82).

In addition to these studies showing how lymphocyte-intrinsic adrenergic signaling may influence immune function, adrenergic signaling is likely to have varying cell-intrinsic effects on different hematopoietic subsets and is a topic of ongoing investigation. For instance, Spiegel et al. (148) reported that human CD34 ${ }^{+}$ HSPCs upregulate expression of $\beta$-ARs in response to G-CSF treatment. The authors also provided evidence for synergistic effects of G-CSF and adrenergic signaling (by EP) in HSPCs, including enhanced proliferative and repopulation potential after engraftment. These effects were mediated, at least in part, by activation of the Wnt- $\beta$-catenin signaling pathway. The finding that G-CSF modulates immune cell responsiveness to adrenergic signals provided an alternative explanation for how G-CSF signals function in concert with neuron-derived adrenergic signals to promote HSPC mobilization as originally noted by Katayama et al. (139).

\section{CONCLUDING REMARKS}

In this review we have attempted to give an overview of the ways in which the central circadian clock regulates rhythmic catecholamine synthesis and secretion, describe how catecholamines signal through adrenergic receptors in immune 
cell targets, and highlight a few publications which incorporate all of these aspects in a demonstration of the physiological significance of circadian regulation of immunity through adrenergic signaling. With this background regarding the ways in which circadian clocks regulate adrenergic signals in mind, the interested reader is encouraged to survey the many reviews detailing how adrenergic signaling more broadly affects immunity. We anticipate that future studies examining the effects of adrenergic signaling on immunity may be benefitted from a broader understanding of adrenergic signaling as a process regulated by circadian mechanisms, with potential implications for modulation of immune outcomes.

\section{AUTHOR CONTRIBUTIONS}

SL and KS both wrote and edited the manuscript. Both authors contributed to the article and approved the submitted version.

\section{REFERENCES}

1. Ralph MR, Foster RG, Davis FC, Menaker M. Transplanted suprachiasmatic nucleus determines circadian period. Science. (1990) 247:975-8. doi: 10.1126/science.2305266

2. van den Pol AN. Glutamate and aspartate immunoreactivity in hypothalamic presynaptic axons. J Neurosci (1991) 11:2087101. doi: 10.1523/JNEUROSCI.11-07-02087.1991

3. Chen D, Buchanan GF, Ding JM, Hannibal J, Gillette MU. Pituitary adenylyl cyclase-activating peptide: a pivotal modulator of glutamatergic regulation of the suprachiasmatic circadian clock. Proc Natl Acad Sci USA. (1999) 96:13468-73. doi: 10.1073/pnas.96.23.13468

4. Hendrickson AE, Wagoner N, Cowan WM. An autoradiographic and electron microscopic study of retino-hypothalamic connections. Z Zellforsch Mikrosk Anat. (1972) 135:1-26. doi: 10.1007/BF00307084

5. Moore RY, Lenn NJ. A retinohypothalamic projection in the rat. J Comp Neurol. (1972) 146:1-14. doi: 10.1002/cne.901460102

6. Yan L, Takekida S, Shigeyoshi Y, Okamura H. Per1 and Per2 gene expression in the rat suprachiasmatic nucleus: circadian profile and the compartment-specific response to light. Neuroscience. (1999) 94:14150. doi: 10.1016/S0306-4522(99)00223-7

7. Paul KN, Fukuhara C, Karom M, Tosini G, Albers HE. AMPA/kainate receptor antagonist DNQX blocks the acute increase of Per2 mRNA levels in most but not all areas of the SCN. Brain Res Mol Brain Res. (2005) 139:129-36. doi: 10.1016/j.molbrainres.2005.05.017

8. Tischkau SA, Gallman EA, Buchanan GF, Gillette MU. Differential cAMP gating of glutamatergic signaling regulates long-term state changes in the suprachiasmatic circadian clock. J Neurosci. (2000) 20:78307. doi: 10.1523/JNEUROSCI.20-20-07830.2000

9. Dolmetsch RE, Pajvani U, Fife K, Spotts JM, Greenberg ME. Signaling to the nucleus by an L-type calcium channel-calmodulin complex through the MAP kinase pathway. Science. (2001) 294:333-9. doi: 10.1126/science. 1063395

10. Cheng AH, Bouchard-Cannon P, Hegazi S, Lowden C, Fung SW, Chiang $\mathrm{CK}$, et al. SOX2-dependent transcription in clock neurons promotes the robustness of the central circadian pacemaker. Cell Rep. (2019) 26:3191-202 e8. doi: 10.1016/j.celrep.2019.02.068

11. Gekakis N, Staknis D, Nguyen HB, Davis FC, Wilsbacher LD, King DP, et al. Role of the CLOCK protein in the mammalian circadian mechanism. Science. (1998) 280:1564-9. doi: 10.1126/science.280.53 69.1564

12. Hogenesch JB, Gu YZ, Jain S, Bradfield CA. The basic-helix-loophelix-PAS orphan MOP3 forms transcriptionally active complexes with

\section{FUNDING}

This work was supported by grants from the Japan Society for the Promotion of Science (JP15H05656, JP15K15153, JP15H01157, and JP19H03489), the Japan Science and Technology Agency (PRESTO), the Japan Agency for Medical Research and Development (JP19gm6210007) and the Takeda Science Foundation to KS. SL was a recipient of the Kishimoto Foundation Fellowship.

\section{ACKNOWLEDGMENTS}

We thank the members of the Suzuki laboratory for helpful comments on the manuscript. We apologize to the many researchers whose work could not be recognized in this review due to space limitations. circadian and hypoxia factors. Proc Natl Acad Sci USA. (1998) 95:54749. doi: 10.1073/pnas.95.10.5474

13. Jin X, Shearman LP, Weaver DR, Zylka MJ, de Vries GJ, Reppert SM. A molecular mechanism regulating rhythmic output from the suprachiasmatic circadian clock. Cell. (1999) 96:57-68. doi: 10.1016/S0092-8674(00)80959-9

14. Kume K, Zylka MJ, Sriram S, Shearman LP, Weaver DR, Jin $\mathrm{X}$, et al. mCRY1 and mCRY2 are essential components of the negative limb of the circadian clock feedback loop. Cell. (1999) 98:193-205. doi: 10.1016/S0092-8674(00)81014-4

15. Chiou YY, Yang Y, Rashid N, Ye R, Selby CP, Sancar A. Mammalian period represses and de-represses transcription by displacing CLOCKBMAL1 from promoters in a Cryptochrome-dependent manner. Proc Natl Acad Sci USA. (2016) 113:E6072-9. doi: 10.1073/pnas.16129 17113

16. Giguere V, Tini M, Flock G, Ong E, Evans RM, Otulakowski G. Isoformspecific amino-terminal domains dictate DNA-binding properties of ROR alpha, a novel family of orphan hormone nuclear receptors. Genes Dev. (1994) 8:538-53. doi: 10.1101/gad.8.5.538

17. Sato TK, Panda S, Miraglia LJ, Reyes TM, Rudic RD, McNamara $\mathrm{P}$, et al. A functional genomics strategy reveals Rora as a component of the mammalian circadian clock. Neuron. (2004) 43:527-37. doi: 10.1016/j.neuron.2004.07.018

18. Guillaumond F, Dardente H, Giguere V, Cermakian N. Differential control of Bmall circadian transcription by REV-ERB and ROR nuclear receptors. $J$ Biol Rhythms. (2005) 20:391-403. doi: 10.1177/0748730405277232

19. Akashi M, Takumi T. The orphan nuclear receptor RORalpha regulates circadian transcription of the mammalian core-clock Bmal1. Nat Struct Mol Biol. (2005) 12:441-8. doi: 10.1038/nsmb925

20. Dunlap JC. Molecular bases for circadian clocks. Cell. (1999) 96:27190. doi: 10.1016/S0092-8674(00)80566-8

21. Young MW. Life's 24-hour clock: molecular control of circadian rhythms in animal cells. Trends Biochem Sci. (2000) 25:6016. doi: 10.1016/S0968-0004(00)01695-9

22. Patke A, Young MW, Axelrod S. Molecular mechanisms and physiological importance of circadian rhythms. Nat Rev Mol Cell Biol. (2019) 21:6784. doi: 10.1038/s41580-019-0179-2

23. White DC, Hata JA, Shah AS, Glower DD, Lefkowitz RJ, Koch WJ. Preservation of myocardial beta-adrenergic receptor signaling delays the development of heart failure after myocardial infarction. Proc Natl Acad Sci USA. (2000) 97:5428-33. doi: 10.1073/pnas.090 091197

24. Wu H, Lee J, Vincent LG, Wang Q, Gu M, Lan F, et al. Epigenetic regulation of phosphodiesterases $2 \mathrm{~A}$ and $3 \mathrm{~A}$ underlies compromised beta-adrenergic 
signaling in an iPSC model of dilated cardiomyopathy. Cell Stem Cell. (2015) 17:89-100. doi: 10.1016/j.stem.2015.04.020

25. Bachman ES, Dhillon H, Zhang CY, Cinti S, Bianco AC, Kobilka BK, et al. betaAR signaling required for diet-induced thermogenesis and obesity resistance. Science. (2002) 297:843-5. doi: 10.1126/science.1073160

26. Zeng W, Pirzgalska RM, Pereira MM, Kubasova N, Barateiro A, Seixas E, et al. Sympathetic neuro-adipose connections mediate leptin-driven lipolysis. Cell. (2015) 163:84-94. doi: 10.1016/j.cell.2015.08.055

27. Tanoue A, Nasa Y, Koshimizu T, Shinoura H, Oshikawa S, Kawai $\mathrm{T}$, et al. The alpha(1D)-adrenergic receptor directly regulates arterial blood pressure via vasoconstriction. J Clin Invest. (2002) 109:76575. doi: 10.1172/JCI200214001

28. Philipp M, Brede ME, Hadamek K, Gessler M, Lohse MJ, Hein L. Placental alpha(2)-adrenoceptors control vascular development at the interface between mother and embryo. Nat Genet. (2002) 31:3115. doi: $10.1038 /$ ng919

29. Sanders VM. The beta2-adrenergic receptor on $T$ and $B$ lymphocytes: do we understand it yet? Brain Behav Immun. (2012) 26:195-200. doi: 10.1016/j.bbi.2011.08.001

30. Sanders VM, Straub RH. Norepinephrine, the beta-adrenergic receptor, and immunity. Brain Behav Immun. (2002) 16:290332. doi: 10.1006/brbi.2001.0639

31. Elenkov IJ, Wilder RL, Chrousos GP, Vizi ES. The sympathetic nerve-an integrative interface between two supersystems: the brain and the immune system. Pharmacol Rev. (2000) 52:595-638. Avalable online at: http:// pharmrev.aspetjournals.org/content/52/4/595

32. Guo X, Wakade AR. Differential secretion of catecholamines in response to peptidergic and cholinergic transmitters in rat adrenals. J Physiol. (1994) 475:539-45. doi: 10.1113/jphysiol.1994.sp020092

33. Pincus G. A Diurnal rhythm in the excretion of urinary ketosteroids by young men1. J. Clin. Endocrinol. Metab. (1943) 3:195-9. doi: 10.1210/jcem-3-4-195

34. Andrews RV, Folk GE. Jr. Circadian metabolic patterns in cultured hamster adrenal glands. Comp Biochem Physiol. (1964) 11:393-409. doi: 10.1016/0010-406X(64)90006-4

35. Moore RY, Eichler VB. Loss of a circadian adrenal corticosterone rhythm following suprachiasmatic lesions in the rat. Brain Res. (1972) 42:2016. doi: 10.1016/0006-8993(72)90054-6

36. Linsell CR, Lightman SL, Mullen PE, Brown MJ, Causon RC. Circadian rhythms of epinephrine and norepinephrine in man. J Clin Endocrinol Metab. (1985) 60:1210-5. doi: 10.1210/jcem-60-6-1210

37. De Boer SF, Van der Gugten J. Daily variations in plasma noradrenaline, adrenaline and corticosterone concentrations in rats. Physiol Behav. (1987) 40:323-8. doi: 10.1016/0031-9384(87)90054-0

38. Akerstedt T. Altered sleep/wake patterns and circadian rhythms. Laboratory and field studies of sympathoadrenomedullary and related variables. Acta Physiol Scand Suppl. (1979) 469:1-48.

39. Froberg JE, Karlsson CG, Levi L, Lidberg L. Circadian rhythms of catecholamine excretion, shooting range performance and selfratings of fatigue during sleep deprivation. Biol Psychol. (1975) 2:175-88. doi: 10.1016/0301-0511(75)90018-6

40. Akerstedt T, Levi L. Circadian rhythms in the secretion of cortisol, adrenaline and noradrenaline. Eur J Clin Invest. (1978) 8:57-8. doi: 10.1111/j.1365-2362.1978.tb00811.x

41. Stanley BG, Schwartz DH, Hernandez L, Hoebel BG, Leibowitz SF. Patterns of extracellular norepinephrine in the paraventricular hypothalamus: relationship to circadian rhythm and deprivation-induced eating behavior. Life Sci. (1989) 45:275-82. doi: 10.1016/0024-3205(89)90136-7

42. Ziegler MG, Lake CR, Wood JH, Brooks BR, Ebert MH. Relationship between norepinephrine in blood and cerebrospinal fluid in the presence of a blood-cerebrospinal fluid barrier for norepinephrine. J Neurochem. (1977) 28:677-9. doi: 10.1111/j.1471-4159.1977.tb10444.x

43. Ziegler MC, Lake CR, Wood JH, Ebert MH. Circadian rhythm in cerebrospinal fluid noradrenaline of man and monkey. Nature. (1976) 264:656-8. doi: 10.1038/264656a0

44. Brownstein M, Axelrod J. Pineal gland: 24-hour rhythm in norepinephrine turnover. Science. (1974) 184:163-5. doi: 10.1126/science.184.4133.163
45. Simonneaux V, Ribelayga C. Generation of the melatonin endocrine message in mammals: a review of the complex regulation of melatonin synthesis by norepinephrine, peptides, and other pineal transmitters. Pharmacol Rev. (2003) 55:325-95. doi: 10.1124/pr.55.2.2

46. Silva SO, Rodrigues MR, Ximenes VF, Bueno-da-Silva AE, AmaranteMendes GP, Campa A. Neutrophils as a specific target for melatonin and kynuramines: effects on cytokine release. J Neuroimmunol. (2004) 156:14652. doi: 10.1016/j.jneuroim.2004.07.015

47. Carrillo-Vico A, Lardone PJ, Fernandez-Santos JM, Martin-Lacave I, Calvo JR, Karasek M, et al. Human lymphocyte-synthesized melatonin is involved in the regulation of the interleukin-2/interleukin-2 receptor system. J Clin Endocrinol Metab. (2005) 90:992-1000. doi: 10.1210/jc.2004-1429

48. Deng WG, Tang ST, Tseng HP, Wu KK. Melatonin suppresses macrophage cyclooxygenase-2 and inducible nitric oxide synthase expression by inhibiting p52 acetylation and binding. Blood. (2006) 108:518-24. doi: 10.1182/blood-2005-09-3691

49. Marcola M, da Silveira Cruz-Machado S, Fernandes PA, Monteiro AW, Markus RP, Tamura EK. Endothelial cell adhesiveness is a function of environmental lighting and melatonin level. J Pineal Res. (2013) 54:1629. doi: 10.1111/j.1600-079X.2012.01025.x

50. Lotufo CM, Yamashita CE, Farsky SH, Markus RP. Melatonin effect on endothelial cells reduces vascular permeability increase induced by leukotriene B4. Eur J Pharmacol. (2006) 534:25863. doi: 10.1016/j.ejphar.2006.01.050

51. Kalsbeek A, Fliers E, Franke AN, Wortel J, Buijs RM. Functional connections between the suprachiasmatic nucleus and the thyroid gland as revealed by lesioning and viral tracing techniques in the rat. Endocrinology. (2000) 141:3832-41. doi: 10.1210/endo.141.10.7709

52. Gillette MU, Reppert SM. The hypothalamic suprachiasmatic nuclei: circadian patterns of vasopressin secretion and neuronal activity in vitro. Brain Res Bull. (1987) 19:135-9. doi: 10.1016/0361-9230(87)90176-6

53. Alexander LD, Sander LD. Vasoactive intestinal peptide stimulates ACTH and corticosterone release after injection into the PVN. Regul Pept. (1994) 51:221-7. doi: 10.1016/0167-0115(94)90068-X

54. Loh DH, Abad C, Colwell CS, Waschek JA. Vasoactive intestinal peptide is critical for circadian regulation of glucocorticoids. Neuroendocrinology. (2008) 88:246-55. doi: 10.1159/000140676

55. Graham ES, Littlewood P, Turnbull Y, Mercer JG, Morgan PJ, Barrett P. Neuromedin- $\mathrm{U}$ is regulated by the circadian clock in the SCN of the mouse. Eur J Neurosci. (2005) 21:814-9. doi: 10.1111/j.1460-9568.2005.03923.x

56. Kwak SP, Young EA, Morano I, Watson SJ, Akil H. Diurnal corticotropinreleasing hormone mRNA variation in the hypothalamus exhibits a rhythm distinct from that of plasma corticosterone. Neuroendocrinology. (1992) 55:74-83. doi: $10.1159 / 000126099$

57. Wurtman RJ, Axelrod J. Adrenaline synthesis: control by the pituitary gland and adrenal glucocorticoids. Science. (1965) 150:1464-5. doi: 10.1126/science.150.3702.1464

58. Kent C, Parker KG. Effects of ACTH and aminoglutethimide on the catecholamine content and chromaffin cell morphology of the adrenal medulla of the neonatal rat. J Anat. (1993) 183 (Pt 3)601-7.

59. Buijs RM, Wortel J, Van Heerikhuize JJ, Feenstra MG, Ter Horst GJ, Romijn $\mathrm{HJ}$, et al. Anatomical and functional demonstration of a multisynaptic suprachiasmatic nucleus adrenal (cortex) pathway. Eur J Neurosci. (1999) 11:1535-44. doi: 10.1046/j.1460-9568.1999.00575.x

60. Charlton BG. Adrenal cortical innervation and glucocorticoid secretion. $J$ Endocrinol. (1990) 126:5-8. doi: 10.1677/joe.0.1260005

61. Appel NM, Elde RP. The intermediolateral cell column of the thoracic spinal cord is comprised of target-specific subnuclei: evidence from retrograde transport studies and immunohistochemistry. J Neurosci. (1988) 8:176775. doi: 10.1523/JNEUROSCI.08-05-01767.1988

62. Edwards AV, Jones CT. Autonomic control of adrenal function. J Anat. (1993) 183(Pt 2)291-307.

63. Coupland RE, Parker TL, Kesse WK, Mohamed AA. The innervation of the adrenal gland. III. Vagal innervation. J Anat. (1989) 163:173-81.

64. Niijima A. Electrophysiological study on the vagal innervation of the adrenal gland in the rat. J Auton Nerv Syst. (1992) 41:8792. doi: $10.1016 / 0165-1838(92) 90130-9$ 
65. Marley PD. Desensitization of the nicotinic secretory response of adrenal chromaffin cells. Trends Pharmacol Sci. (1988) 9:102-7. doi: 10.1016/0165-6147(88)90177-0

66. Eiden LE, Jiang SZ. What's new in endocrinology: the chromaffin cell. Front Endocrinol (Lausanne). (2018) 9:711. doi: 10.3389/fendo.2018.00711

67. Ishida $A$, Mutoh $\mathrm{T}$, Ueyama $\mathrm{T}$, Bando $\mathrm{H}$, Masubuchi $\mathrm{S}$, Nakahara D, et al. Light activates the adrenal gland: timing of gene expression and glucocorticoid release. Cell Metab. (2005) 2:297-307. doi: 10.1016/j.cmet.2005.09.009

68. Niijima A, Nagai K, Nagai N, Akagawa H. Effects of light stimulation on the activity of the autonomic nerves in anesthetized rats. Physiol Behav. (1993) 54:555-61. doi: 10.1016/0031-9384(93)90249-F

69. Fahrenkrug J, Hannibal J, Georg B. Diurnal rhythmicity of the canonical clock genes Per1, Per2 and Bmal1 in the rat adrenal gland is unaltered after hypophysectomy. J Neuroendocrinol. (2008) 20:323-9. doi: 10.1111/j.1365-2826.2008.01651.x

70. Cadd GG, Hoyle GW, Quaife CJ, Marck B, Matsumoto AM, Brinster RL, et al. Alteration of neurotransmitter phenotype in noradrenergic neurons of transgenic mice. Mol Endocrinol. (1992) 6:1951-60. doi: 10.1210/mend.6.11.1480181

71. Wurtman RJ, Axelrod J. Control of enzymatic synthesis of adrenaline in the adrenal medulla by adrenal cortical steroids. J Biol Chem. (1966) 241:2301-5.

72. Oster H, Damerow S, Hut RA, Eichele G. Transcriptional profiling in the adrenal gland reveals circadian regulation of hormone biosynthesis genes and nucleosome assembly genes. J Biol Rhythms. (2006) 21:35061. doi: 10.1177/0748730406293053

73. Bornstein SR, Engeland WC, Ehrhart-Bornstein M, Herman JP. Dissociation of ACTH and glucocorticoids. Trends Endocrinol Metab. (2008) 19:17580. doi: 10.1016/j.tem.2008.01.009

74. Vermes I, Beishuizen A. The hypothalamic-pituitary-adrenal response to critical illness. Best Pract Res Clin Endocrinol Metab. (2001) 15:495511. doi: 10.1053/beem.2001.0166

75. Kalsbeek A, van der Spek R, Lei J, Endert E, Buijs RM, Fliers E. Circadian rhythms in the hypothalamo-pituitary-adrenal (HPA) axis. Mol Cell Endocrinol. (2012) 349:20-9. doi: 10.1016/j.mce.2011.06.042

76. Felten DL, Felten SY, Carlson SL, Olschowka JA, Livnat S. Noradrenergic and peptidergic innervation of lymphoid tissue. J Immunol. (1985) 135:755s-65s.

77. Williams JM, Felten DL. Sympathetic innervation of murine thymus and spleen: a comparative histofluorescence study. Anat Rec. (1981) 199:53142. doi: 10.1002/ar.1091990409

78. EULER USV. A specific sympathomimetic ergone in adrenergic nerve fibres (sympathin) and its relations to adrenaline and nor-adrenaline. Acta Physiologica Scandinavica. (1946) 12:7397. doi: 10.1111/j.1748-1716.1946.tb00368.x

79. Esler M, Willett I, Leonard P, Hasking G, Johns J, Little P, et al. Plasma noradrenaline kinetics in humans. J Auton Nerv Syst. (1984) 11:12544. doi: 10.1016/0165-1838(84)90071-7

80. Schomig A, Richardt G. Cardiac sympathetic activity in myocardial ischemia: release and effects of noradrenaline. Basic Res Cardiol. (1990) 85(Suppl. 1):9-30. doi: 10.1007/978-3-662-11038-6_2

81. Von Euler U, Franksson C, Hellstrom J. Adrenaline and noradrenaline output in urine after unilateral and bilateral adrenalectomy in man. Acta Physiol Scand. (1954) 31:1-5. doi: 10.1111/j.1748-1716.1954.tb0 1107.x

82. Suzuki K, Hayano Y, Nakai A, Furuta F, Noda M. Adrenergic control of the adaptive immune response by diurnal lymphocyte recirculation through lymph nodes. J Exp Med. (2016) 213:2567-74. doi: 10.1084/jem.201 60723

83. Ahlquist RP. The adrenergic receptor. J Pharm Sci. (1966) 55:35967. doi: 10.1002/jps.2600550402

84. Ahlquist RP. Historical perspective. classification of adrenoreceptors. $J$ Auton Pharmacol. (1980) 1:101-6. doi: 10.1111/j.1474-8673.1980.tb00445.x

85. Berthelsen S, Pettinger WA. A functional basis for classification of alpha-adrenergic receptors. Life Sci. (1977) 21:595606. doi: 10.1016/0024-3205(77)90066-2

86. Emorine LJ, Marullo S, Briend-Sutren MM, Patey G, Tate K, DelavierKlutchko C, et al. Molecular characterization of the human beta 3-adrenergic receptor. Science. (1989) 245:1118-21. doi: 10.1126/science.2570461
87. Frielle T, Collins S, Daniel KW, Caron MG, Lefkowitz RJ, Kobilka BK. Cloning of the cDNA for the human beta 1-adrenergic receptor. Proc Natl Acad Sci USA. (1987) 84:7920-4. doi: 10.1073/pnas.84.22.7920

88. Kobilka BK, Dixon RA, Frielle T, Dohlman HG, Bolanowski MA, Sigal IS, et al. cDNA for the human beta 2-adrenergic receptor: a protein with multiple membrane-spanning domains and encoded by a gene whose chromosomal location is shared with that of the receptor for platelet-derived growth factor. Proc Natl Acad Sci USA. (1987) 84:4650. doi: 10.1073/pnas.84.1.46

89. Ramer-Quinn DS, Baker RA, Sanders VM. Activated T helper 1 and T helper 2 cells differentially express the beta-2-adrenergic receptor: a mechanism for selective modulation of T helper 1 cell cytokine production. J Immunol. (1997) 159:4857-67.

90. Sanders VM, Baker RA, Ramer-Quinn DS, Kasprowicz DJ, Fuchs BA, Street NE. Differential expression of the beta2-adrenergic receptor by Th1 and Th2 clones: implications for cytokine production and B cell help. J Immunol. (1997) 158:4200-10.

91. Gonzalez-Cabrera PJ, Shi T, Yun J, McCune DF, Rorabaugh BR, Perez DM. Differential regulation of the cell cycle by alpha1-adrenergic receptor subtypes. Endocrinology. (2004) 145:5157-67. doi: 10.1210/en.2004-0728

92. Liu H, Zhang CH, Ammanamanchi N, Suresh S, Lewarchik C, Rao K, et al. Control of cytokinesis by beta-adrenergic receptors indicates an approach for regulating cardiomyocyte endowment. Sci Transl Med. (2019) 11:116. doi: $10.1101 / 782920$

93. Maestroni GJ. Dendritic cell migration controlled by alpha 1b-adrenergic receptors. J Immunol. (2000) 165:67437. doi: 10.4049/jimmunol.165.12.6743

94. Grisanti LA, Evanson J, Marchus E, Jorissen H, Woster AP, DeKrey $\mathrm{W}$, et al. Pro-inflammatory responses in human monocytes are beta1adrenergic receptor subtype dependent. Mol Immunol. (2010) 47:124454. doi: 10.1016/j.molimm.2009.12.013

95. Agarwal SK, Marshall GD. Jr. Beta-adrenergic modulation of human type-1/type-2 cytokine balance. J Allergy Clin Immunol. (2000) 105:918. doi: 10.1016/S0091-6749(00)90183-0

96. Tan KS, Nackley AG, Satterfield K, Maixner W, Diatchenko L, Flood PM. Beta2 adrenergic receptor activation stimulates pro-inflammatory cytokine production in macrophages via PKA- and NF-kappaB-independent mechanisms. Cell Signal. (2007) 19:251-60. doi: 10.1016/j.cellsig.2006.06.007

97. Dessauer CW. Adenylyl cyclase-A-kinase anchoring protein complexes: the next dimension in cAMP signaling. Mol Pharmacol. (2009) 76:93541. doi: 10.1124/mol.109.059345

98. Duan B, Davis R, Sadat EL, Collins J, Sternweis PC, Yuan D, et al. Distinct roles of adenylyl cyclase VII in regulating the immune responses in mice. $J$ Immunol. (2010) 185:335-44. doi: 10.4049/jimmunol.0903474

99. Smith KE, Gu C, Fagan KA, Hu B, Cooper DM. Residence of adenylyl cyclase type 8 in caveolae is necessary but not sufficient for regulation by capacitative $\mathrm{Ca}(2+)$ entry. J Biol Chem. (2002) 277:602531. doi: 10.1074/jbc.M109615200

100. McDonald PH, Chow CW, Miller WE, Laporte SA, Field ME, Lin FT, et al. Beta-arrestin 2: a receptor-regulated MAPK scaffold for the activation of JNK3. Science. (2000) 290:1574-7. doi: 10.1126/science.290.5496.1574

101. Lefkowitz RJ, Shenoy SK. Transduction of receptor signals by beta-arrestins. Science. (2005) 308:512-7. doi: 10.1126/science.1109237

102. Elenkov IJ, Papanicolaou DA, Wilder RL, Chrousos GP. Modulatory effects of glucocorticoids and catecholamines on human interleukin-12 and interleukin-10 production: clinical implications. Proc Assoc Am Physicians. (1996) 108:374-81.

103. Elenkov IJ, Hasko G, Kovacs KJ, Vizi ES. Modulation of lipopolysaccharideinduced tumor necrosis factor-alpha production by selective alphaand beta-adrenergic drugs in mice. J Neuroimmunol. (1995) 61:12331. doi: 10.1016/0165-5728(95)00080-L

104. Muthu K, Iyer S, He LK, Szilagyi A, Gamelli RL, Shankar R, et al. Murine hematopoietic stem cells and progenitors express adrenergic receptors. J Neuroimmunol. (2007) 186:27-36. doi: 10.1016/j.jneuroim.2007. 02.007

105. Schulze W, Fu ML. Localization of alpha 1-adrenoceptors in rat and human hearts by immunocytochemistry. Mol Cell Biochem. (1996) 164:15965. doi: $10.1007 / \mathrm{BF} 00408653$ 
106. Jetschmann JU, Benschop RJ, Jacobs R, Kemper A, Oberbeck R, Schmidt RE, et al. Expression and in-vivo modulation of alpha- and beta-adrenoceptors on human natural killer (CD16+) cells. J Neuroimmunol. (1997) 74:15964. doi: 10.1016/S0165-5728(96)00221-4

107. Miksa M, Wu R, Zhou M, Wang P. Sympathetic excitotoxicity in sepsis: pro-inflammatory priming of macrophages by norepinephrine. Front Biosci. (2005) 10:2217-29. doi: 10.2741/1691

108. Yanagawa $Y$, Matsumoto $M$, Togashi H. Enhanced dendritic cell antigen uptake via alpha2 adrenoceptor-mediated PI3K activation following brief exposure to noradrenaline. J Immunol. (2010) 185:5762-8. doi: 10.4049/jimmunol.1001899

109. Titinchi S, Clark B. Alpha 2-adrenoceptors in human lymphocytes: direct characterisation by $[3 \mathrm{H}]$ yohimbine binding. Biochem Biophys Res Commun. (1984) 121:1-7. doi: 10.1016/0006-291X(84)90679-X

110. Goin JC, Sterin-Borda L, Borda ES, Finiasz M, Fernandez J, de Bracco MM. Active alpha 2 and beta adrenoceptors in lymphocytes from patients with chronic lymphocytic leukemia. Int J Cancer. (1991) 49:17881. doi: $10.1002 /$ ijc. 2910490205

111. Graham RM, Perez DM, Hwa J, Piascik MT. alpha 1-adrenergic receptor subtypes. Molecular structure, function, and signaling. Circ Res. (1996) 78:737-49. doi: 10.1161/01.RES.78.5.737

112. Limbird LE. Receptors linked to inhibition of adenylate cyclase: additional signaling mechanisms. FASEB J. (1988) 2:2686-95. doi: 10.1096/fasebj.2.11.2840317

113. Fain JN, Garcia-Sainz JA. Role of phosphatidylinositol turnover in alpha 1 and of adenylate cyclase inhibition in alpha 2 effects of catecholamines. Life Sci. (1980) 26:1183-94. doi: 10.1016/0024-3205(80)90062-4

114. Foote SL, Bloom FE, Aston-Jones G. Nucleus locus ceruleus: new evidence of anatomical and physiological specificity. Physiol Rev. (1983) 63:844914. doi: 10.1152/physrev.1983.63.3.844

115. Foote SL, Aston-Jones G, Bloom FE. Impulse activity of locus coeruleus neurons in awake rats and monkeys is a function of sensory stimulation and arousal. Proc Natl Acad Sci USA. (1980) 77:3033-7. doi: 10.1073/pnas.77.5.3033

116. McCall JG, Al-Hasani R, Siuda ER, Hong DY, Norris AJ, Ford $\mathrm{CP}$, et al. $\mathrm{CRH}$ engagement of the locus coeruleus noradrenergic system mediates stress-induced anxiety. Neuron. (2015) 87:60520. doi: 10.1016/j.neuron.2015.07.002

117. Giustino TF, Fitzgerald PJ, Ressler RL, Maren S. Locus coeruleus toggles reciprocal prefrontal firing to reinstate fear. Proc Natl Acad Sci USA. (2019) 116:8570-75. doi: 10.1073/pnas.1814278116

118. Aston-Jones G, Chen S, Zhu Y, Oshinsky ML. A neural circuit for circadian regulation of arousal. Nat Neurosci. (2001) 4:732-8. doi: 10.1038/89522

119. Gonzalez MM, Aston-Jones G. Circadian regulation of arousal: role of the noradrenergic locus coeruleus system and light exposure. Sleep. (2006) 29:1327-36. doi: 10.1093/sleep/29.10.1327

120. Rajkowski J, Kubiak P, Aston-Jones G. Locus coeruleus activity in monkey: phasic and tonic changes are associated with altered vigilance. Brain Res Bull. (1994) 35:607-16. doi: 10.1016/0361-9230(94)90175-9

121. Hobson JA, McCarley RW, Wyzinski PW. Sleep cycle oscillation: reciprocal discharge by two brainstem neuronal groups. Science. (1975) 189:558. doi: 10.1126/science.1094539

122. Sugama S, Takenouchi T, Hashimoto M, Ohata H, Takenaka Y, Kakinuma Y. Stress-induced microglial activation occurs through beta-adrenergic receptor: noradrenaline as a key neurotransmitter in microglial activation. J Neuroinflamm. (2019) 16:266. doi: 10.1186/s12974-019-1632-Z

123. Zhang Y, Chen K, Sloan SA, Bennett ML, Scholze AR, O'Keeffe S, et al. An RNA-sequencing transcriptome and splicing database of glia, neurons, and vascular cells of the cerebral cortex. J Neurosci. (2014) 34:1192947. doi: 10.1523/JNEUROSCI.1860-14.2014

124. Stowell RD, Sipe GO, Dawes RP, Batchelor HN, Lordy KA, Whitelaw BS, et al. Noradrenergic signaling in the wakeful state inhibits microglial surveillance and synaptic plasticity in the mouse visual cortex. Nat Neurosci. (2019) 22:1782-92. doi: 10.1038/s41593-019-0514-0

125. Liu YU, Ying Y, Li Y, Eyo UB, Chen T, Zheng J, et al. Neuronal network activity controls microglial process surveillance in awake mice via norepinephrine signaling. Nat Neurosci. (2019) 22:1771-81. doi: 10.1038/s41593-019-0511-3
126. Dello Russo C, Boullerne AI, Gavrilyuk V, Feinstein DL. Inhibition of microglial inflammatory responses by norepinephrine: effects on nitric oxide and interleukin-1beta production. J Neuroinflammation. (2004) 1:9. doi: 10.1186/1742-2094-1-9

127. Mann DM, Yates PO. Pathological basis for neurotransmitter changes in Parkinson's disease. Neuropathol Appl Neurobiol. (1983) 9:3-19. doi: 10.1111/j.1365-2990.1983.tb00320.x

128. Mann DM, Lincoln J, Yates PO, Stamp JE, Toper S. Changes in the monoamine containing neurones of the human CNS in senile dementia. $\mathrm{BrJ}$ Psychiatry. (1980) 136:533-41. doi: 10.1192/bjp.136.6.533

129. Weinshenker D. Long road to ruin: noradrenergic dysfunction in neurodegenerative disease. Trends Neurosci. (2018) 41:211223. doi: $10.1016 /$ j.tins.2018.01.010

130. Elmadjian F, Pincus G. A study of the diurnal variations in circulating lymphocytes in normal and psychotic subjects. J Clin Endocrinol Metab. (1946) 6:287-94. doi: 10.1210/jcem-6-4-287

131. Halberg F, Visscher MB. Regular diurnal physiological variation in eosinophil levels in five stocks of mice. Proc Soc Exp Biol Med. (1950) 75:8467. doi: 10.3181/00379727-75-18365

132. Suzuki S, Toyabe S, Moroda T, Tada T, Tsukahara A, Iiai T, et al. Circadian rhythm of leucocytes and lymphocytes subsets and its possible correlation with the function of the autonomic nervous system. Clin Exp Immunol. (1997) 110:500-8. doi: 10.1046/j.1365-2249.1997.4411460.x

133. Halberg F, Visscher MB, Bittner JJ. Eosinophil rhythm in mice: range of occurrence; effects of illumination, feeding, and adrenalectomy. Am J Physiol. (1953) 174:109-22. doi: 10.1152/ajplegacy.1953.174.1.109

134. Dimitrov S, Benedict C, Heutling D, Westermann J, Born J, Lange T. Cortisol and epinephrine control opposing circadian rhythms in T cell subsets. Blood. (2009) 113:5134-43. doi: 10.1182/blood-2008-11-190769

135. Golan K, Kumari A, Kollet O, Khatib-Massalha E, Subramaniam MD, Ferreira ZS, et al. Daily onset of light and darkness differentially controls hematopoietic stem cell differentiation and maintenance. Cell Stem Cell. (2018) 23:572-85 e7. doi: 10.1016/j.stem.2018.08.002

136. He W, Holtkamp S, Hergenhan SM, Kraus K, de Juan A, Weber J, et al. Circadian expression of migratory factors establishes lineage-specific signatures that guide the homing of leukocyte subsets to tissues. Immunity. (2018) 49:1175-90 e7. doi: 10.1016/j.immuni.2018.10.007

137. Dougherty TF, White A. Influence of adrenal cortical secretion on blood elements. Science. (1943) 98:367-9. doi: 10.1126/science.98.2547.367

138. Brown HE, Dougherty TF. The diurnal variation of blood leucocytes in normal and adrenalectomized mice. Endocrinology. (1956) 58:36575. doi: 10.1210/endo-58-3-365

139. Katayama Y, Battista M, Kao WM, Hidalgo A, Peired AJ, Thomas $\mathrm{SA}$, et al. Signals from the sympathetic nervous system regulate hematopoietic stem cell egress from bone marrow. Cell. (2006) 124:40721. doi: 10.1016/j.cell.2005.10.041

140. Mendez-Ferrer S, Lucas D, Battista M, Frenette PS. Haematopoietic stem cell release is regulated by circadian oscillations. Nature. (2008) 452:4427. doi: $10.1038 /$ nature 06685

141. Mendez-Ferrer S, Michurina TV, Ferraro F, Mazloom AR, Macarthur $\mathrm{BD}$, Lira SA, et al. Mesenchymal and haematopoietic stem cells form a unique bone marrow niche. Nature. (2010) 466:829-34. doi: 10.1038/nature 09262

142. Scheiermann C, Kunisaki Y, Lucas D, Chow A, Jang JE, Zhang $\mathrm{D}$, et al. Adrenergic nerves govern circadian leukocyte recruitment to tissues. Immunity. (2012) 37:290-301. doi: 10.1016/j.immuni.2012. 05.021

143. Garcia-Garcia A, Korn C, Garcia-Fernandez M, Domingues O, Villadiego J, Martin-Perez D, et al. Dual cholinergic signals regulate daily migration of hematopoietic stem cells and leukocytes. Blood. (2019) 133:22436. doi: 10.1182/blood-2018-08-867648

144. Nakai A, Hayano Y, Furuta F, Noda M, Suzuki K. Control of lymphocyte egress from lymph nodes through beta2-adrenergic receptors. J Exp Med. (2014) 211:2583-98. doi: 10.1084/jem.20141132

145. Druzd D, Matveeva O, Ince L, Harrison U, He W, Schmal $\mathrm{C}$, et al. Lymphocyte circadian clocks control lymph node trafficking and adaptive immune responses. Immunity. (2017) 46:120-32. doi: 10.1016/j.immuni.2016.12.011 
146. Hemmers S, Rudensky AY. The cell-intrinsic circadian clock is dispensable for lymphocyte differentiation and function. Cell Rep. (2015) 11:133949. doi: $10.1016 /$ j.celrep.2015.04.058

147. Yu X, Rollins D, Ruhn KA, Stubblefield JJ, Green CB, Kashiwada M, et al. TH17 cell differentiation is regulated by the circadian clock. Science. (2013) 342:727-30. doi: 10.1126/science. 1243884

148. Spiegel A, Shivtiel S, Kalinkovich A, Ludin A, Netzer N, Goichberg P, et al. Catecholaminergic neurotransmitters regulate migration and repopulation of immature human CD34+ cells through Wnt signaling. Nat Immunol. (2007) 8:1123-31. doi: 10.1038/ni1509
Conflict of Interest: The authors declare that the research was conducted in the absence of any commercial or financial relationships that could be construed as a potential conflict of interest.

Copyright (C) 2020 Leach and Suzuki. This is an open-access article distributed under the terms of the Creative Commons Attribution License (CC BY). The use, distribution or reproduction in other forums is permitted, provided the original author(s) and the copyright owner(s) are credited and that the original publication in this journal is cited, in accordance with accepted academic practice. No use, distribution or reproduction is permitted which does not comply with these terms. 